\title{
Distribution and genesis of the anomalously high porosity zones in the middle-shallow horizons of the northern Songliao Basin
}

\author{
Meng Yuanlin ${ }^{1 *}$, Liang Hongwei', Meng Fanjin ${ }^{1}$, Wu Heyong², Wang Cheng², \\ Xiu Hongwen ${ }^{2}$, Zhang Anda ${ }^{2}$, Li Yaguang ${ }^{2}$ and Guo Rixin ${ }^{3}$ \\ ${ }^{1}$ School of Earth Science, Northeast Petroleum University, Daqing 163318, China \\ ${ }^{2}$ Exploration and Development Research Institute, Daqing Oilfield Company Ltd., Daqing 163712, China \\ ${ }^{3}$ No.1 Petroleum Production Subcompany, Daqing Oilfield Company Ltd., Daqing 163113, China \\ (C) China University of Petroleum (Beijing) and Springer-Verlag Berlin Heidelberg 2010
}

\begin{abstract}
High-quality reservoirs occur in the middle-shallow horizons of the northern Songliao Basin. The distribution and genesis of their anomalously high porosity zones were studied using measured porosities, examination of ordinary thin sections and blue epoxy resin-impregnated thin sections and by SEM. The results show that there are three anomalously high porosity zones at the depth of 450-900 $\mathrm{m}, 1,300-1,900 \mathrm{~m}, 2,050-2,350 \mathrm{~m}$ respectively, named zone i, zone ii and zone iii from top to bottom. Horizontally, zone i and zone ii are distributed all over the basin except in the Southeastern Uplift, while zone iii is only distributed in the Central Depression. Zone i was formed by meteoric water leaching as well as organic acid dissolution. Zones ii and iii were dominantly formed by organic acid dissolution. Additionally, clay mineral transformation generating $\mathrm{H}^{+}$and hydrocarbon emplacement retarding the cementation of sandstones are also important for the formation of zones ii and iii.
\end{abstract}

Key words: Anomalously high porosity zone, diagenetic fluid, organic acid, diagenesis, secondary porosity, hydrocarbon emplacement, sedimentary facies, Songliao Basin

\section{Introduction}

The concept of anomalously high porosity zone has been proposed in recent years on the basis of studying the secondary porosity zones of reservoirs (Bloch et al, 2002; Meng et al, 2006; Berger et al, 2009; Xie et al, 2009). Bloch thought that anomalously high porosity zones were the reservoirs whose porosities were much higher than those of the reservoirs formed in normal deposition and diagenetic environments. Besides the secondary porosity formed by dissolution, the causes of the anomalously high porosity zones also include overpressure, hydrocarbon emplacement and clay coatings on grains. The secondary porosity zone is a common kind of the anomalously high porosity zones. The existence of anomalously high porosity zones in reservoirs of sedimentary basins has become an undisputed fact, but their distribution and genesis still puzzle geologists, although many geologists have been exploring these problems in recent years (Bloch et al, 2002; Ehrenberg and Nadeau, 2005; Sruoga and Rubinstein, 2007; Ehrenberg et al, 2007; 2008; Xiao et al, 2005; Meng, 2004; Meng et al, 2006; 2007;

*Corresponding author. email: QHDMYL@163.com Received July 6, 2009 2008a; 2008b; Jiang et al, 2009; Huang et al, 2009). The Songliao Basin is one of the largest continental hydrocarbonbearing basins in the world. Previous studies show that there are $2-3$ secondary porosity zones vertically in the middleshallow horizons of the northern Songliao Basin, but there is considerable dispute about their distribution and genesis (Xing and Jiang, 1992; Gao and Cai, 1997; Shao et al, 2005; Wang et al, 2007). However, these authors thought that the secondary porosity zones of the northern Songliao Basin were formed by the organic acid dissolving feldspar and laumontite cements. In other words, the previous geologists only discussed the effect of organic acid dissolution, which is only one possible mechanism of the formation of the anomalously high porosity zones. In this paper, a new study on the reservoirs of the northern Songliao Basin was done based on collating data collected over the last half a century. The distribution and genesis of the anomalously high porosity zones in the middle-shallow horizons of the northern Songliao Basin were studied by using data including porosities, thin sections, blue epoxy resin-impregnated thin sections and SEM (scanning electron microscopy) observations to provide scientific foundations for the further development of petroleum exploration and exploitation in the northern Songliao Basin. 


\section{Geological background}

The Songliao Basin is located in the northeastern China, and occupies about $26 \times 10^{4} \mathrm{~km}^{2}$. The Daqing Oilfield is located in the northern Songliao Basin with a total area of about $12 \times 10^{4} \mathrm{~km}^{2}$. Mesozoic and Cenozoic strata occur prominently in the Songliao Basin, with the largest thickness over 10,000 m. Jurassic (J), Cretaceous (K), Eocene (E), Neocene $(\mathrm{N})$ and Quaternary $(\mathrm{N})$ were deposited from bottom to top in the basin. Source, reservoir and seal rocks developed very well in the Cretaceous which is the main exploration and development target interval in the Songliao Basin. The Cretaceous is composed of the Huoshiling $\left(\mathrm{K}_{1} \mathrm{~h}\right)$, Yingcheng $\left(\mathrm{K}_{1} \mathrm{y}\right)$, Denglouku $\left(\mathrm{K}_{1} \mathrm{~d}\right)$, Quantou $\left(\mathrm{K}_{1} \mathrm{q}\right)$, Qingshankou $\left(\mathrm{K}_{2} \mathrm{qn}\right)$, Yaojia $\left(\mathrm{K}_{2} \mathrm{y}\right)$, Nenjiang $\left(\mathrm{K}_{2} \mathrm{n}\right)$, Sifangtai $\left(\mathrm{K}_{2} \mathrm{~s}\right)$ and Mingshui formations $\left(\mathrm{K}_{2} \mathrm{~m}\right)$ from bottom to top. The basin has a typical double-layer structure of lower fracture and upper sag. Its fracturing stage is $\mathrm{K}_{1} \mathrm{~h}-\mathrm{K}_{1} \mathrm{~d}$ involving flysch and volcanoclastic rocks. Its sag stage is $\mathrm{K}_{1} \mathrm{q}-\mathrm{K}_{2} \mathrm{n}$ involving three cycles of semi-deep-deep lacustrine mudstones and shore-shallow lacustrine-fluvial facies sandstones. Lacustrine mudstones and sandstones are the main source rocks and reservoir rocks. There are five sets of oil and gas combinations in the basin. The middle and lower combinations are the main exploration objects in the basin. The middle oil combination includes the Saertu $\left(\mathrm{K}_{2} \mathrm{n}_{1}-\mathrm{K}_{2} \mathrm{y}_{2+3}\right)$, Putaohua $\left(\mathrm{K}_{2} \mathrm{y}_{1}\right)$ and Gaotaizi oil layers $\left(\mathrm{K}_{2} \mathrm{qn}_{2+3}\right)$. The lower oil combination consists of Fuyu $\left(\mathrm{K}_{1} \mathrm{q}_{4}\right)$ and Yangdachengzi oil layers $\left(\mathrm{K}_{1} \mathrm{q}_{3}\right)$. The middle-shallow horizons buried less than 2,500 $\mathrm{m}$ deep which are the focus of this paper, are the entire strata over the $K_{1} q_{2}$. According to the characteristics of structure and stratigraphy of the middle-shallow horizons, and the properties of the deep structures and the basement, the Songliao Basin was divided into six structural units (Wu et al, 2007) (Fig. 1). Moreover, according to the burial history, geothermal history and diagenetic characteristics of the structural units, the Central Depression of the basin was divided into four diagenetic areas: the western Central Depression, the Daqing Placanticline, the eastern Central Depression and the Chaoyanggou Terrace. The Southeastern Uplift was divided into two diagenetic areas: the Changchunling Anticline and the eastern Southeastern Uplift. Together with the North Plunge Area, the Northeastern Uplift and the Western Slope, the northern Songliao Basin is divided into nine diagenetic areas (Fig. 1) (Meng et al, 2010).

\section{Lithological and diagenetic characteristics of the reservoirs}

The sandstones in the middle-shallow horizons of the northern Songliao Basin mainly consist of quartz, feldspar, and rock debris. The quartz content is generally $28 \%-40 \%$. The feldspar content is about $27 \%-45 \%$, usually higher than that of quartz. The rock debris content is $18 \%-48 \%$, and mainly includes intermediate-acidic volcanic rocks, accounting for about $80 \%$ of the rock debris. The heavy minerals are mainly zircon, biotite, chlorite and sphene.

The assessment of diagenetic level was undertaken according to the Petroleum Industry Standards of China (SY/T
5477-2003) the division of diagenetic stages of clastic rocks (Ying et al, 2003). This utilized much data including the homogenization temperatures of fluid inclusions, vitrinite reflectance $R_{0}$, sporopollen color index TAI, GC-MS (gas chromatography-mass spectrometry), pyrolysis analysis, organic acids, X-ray diffraction, ordinary thin sections, blue epoxy resin-impregnated thin sections and SEM data (Meng et al, 2010). The diagenesis of clastic rocks in the middleshallow horizons of the northern Songliao Basin is divided into period $\mathrm{A}$ and $\mathrm{B}$ of early diagenetic stage, sub-period $A_{1}$, sub-period $A_{2}$, and period $B$ of middle diagenetic stage. Their bottom depths are $500 \mathrm{~m}, 1,000 \mathrm{~m}, 1,400 \mathrm{~m}, 2,350 \mathrm{~m}$ and 3,000 $\mathrm{m}$ respectively. In the early diagenetic stage $\mathrm{A}$, the main diagenesis is mechanical compaction, early carbonate cementation and clay cementation. The diagenetic facies are early mechanical compaction and cementation facies, and the pore type is mainly primary porosity. The organic acids began to be generated in the late period $\mathrm{B}$ in the early diagenetic stage. A large amount of organic acids and $\mathrm{CO}_{2}$ were generated by the heat degradation of kerogens and the generation of hydrocarbon in the $A_{1}-A_{2}$ sub-period of the middle diagenetic stage. Organic acids and $\mathrm{CO}_{2}$ dissolving in water formed hot acid diagenetic fluids which dissolved some minerals in the reservoirs and produced secondary porosity. Especially in the $\mathrm{A}_{1}$ and $\mathrm{A}_{2}$ sub-period of the middle diagenetic stage, interlayer water and $\mathrm{H}^{+}$were expelled from mudstones in clay mineral transformation (Hower et al, 1976), which increased the acidity of the diagenetic fluids. The dissolution facies mainly developed from the late period $B$ in the early diagenetic stage to the sub-period $A_{2}$ of the middle diagenetic stage (Table 1). In the $B$ period of the middle diagenetic stage, the source rocks entered into the highly-mature stage, the organic acids generated by kerogens decreased, and the dissolution became weaker and weaker. The cementation began to occur locally, and the main cement was late carbonate cement. The diagenetic facies are mainly dissolution and partial re-cementation. In the middle-shallow horizons of the northern Songliao Basin, only a small part of the Member 3 and Member 4 of the Quantou Formation are in the $\mathrm{B}$ period of the middle diagenetic stage, and most of strata are between the early diagenetic stage and the sub-period $\mathrm{A}_{2}$ of the middle diagenetic stage.

\section{Distribution of the anomalously high porosity zones}

The measured porosities, and examination of blue epoxy resin-impregnated thin sections and SEM of more than 100,000 cores from 2,789 wells indicate that in the middleshallow horizons of the northern Songliao Basin there exist three anomalously high porosity zones vertically, named zone $\mathrm{i}$, zone ii and zone iii from top to bottom. Their depths are 450-900 m, 1,300-1,900 m, 2,050-2,350 m respectively (Fig. 2), which are different from previous studies (Xing and Jiang, 1992; Gao and Cai, 1997). The three high porosity zones in each diagenetic area have quite different characteristics. Zone i with a porosity of $20 \%-40 \%$ has developed in the middle-shallow horizons of the northern Songliao Basin except the Southeastern Uplift. Zone ii with a porosity of 


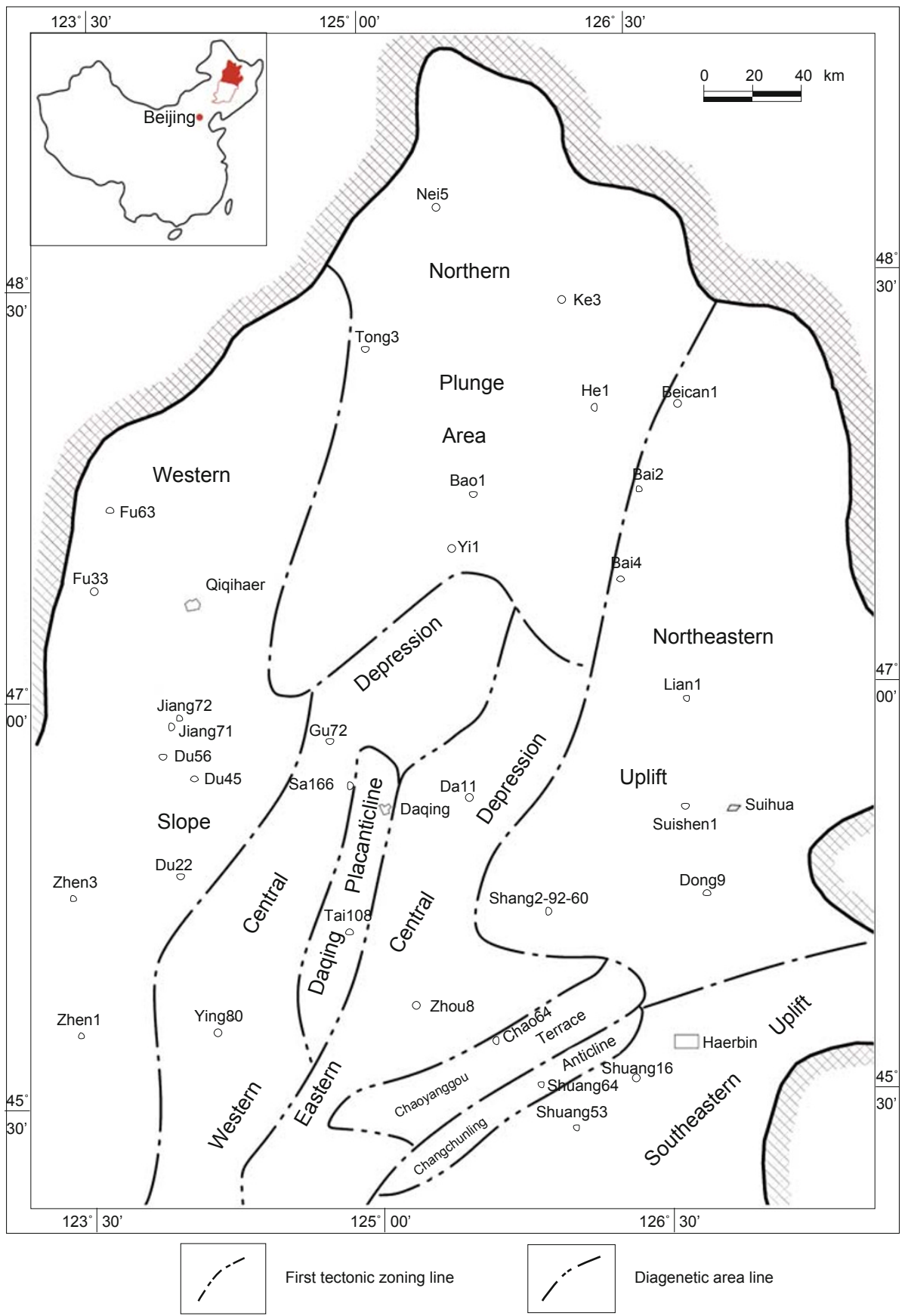

Fig. 1 Tectonic units and diagenetic areas in the middle-shallow horizons of the northern Songliao Basin

$25 \%-35 \%$ is distributed in all the diagenetic areas except the Southeastern Uplift. Zone iii with a porosity of $10 \%$ $20 \%$ is only distributed in the diagenetic areas of the Central Depression. The Heidimiao Oil Layer is mainly located in the anomalously high porosity zone i; the Saertu, Putaohua and Gaotaizi oil layers are mainly in anomalously high porosity zones i and ii; the Fuyu and Yangdachengzi oil layers are distributed in zones ii and iii. The pink dashed line in Fig. 3 represents the normal compaction-cementation trend in the middle-shallow horizons of the northern Songliao Basin, and the curve is based on the observations of blue epoxy resin-impregnated thin sections and the correlation between thin section porosity and core porosity. The porosity of the data points on the left of the curve is the sum of the primary intergranular porosity and the primary intergranular porosity reduced by cementation. The pink dashed line is close to Pittman's normal compaction trend line (Pittman and Larese, 1991). As Fig. 2 shows, a high-porosity zone sometimes penetrates several layers, and the distribution of the high-porosity zones in each diagenetic area is different. For example, the high porosity zone $\mathrm{i}$ in the western Central Depression mainly consists of the Heidimiao Oil Layer, but the high porosity zone $\mathrm{i}$ in the Daqing Placanticline penetrates the Heidimiao, Saertu, and Putaohua oil layers. 
Table 1 Diagenetic stages and main characteristics of the middle-shallow horizons of the northern Songliao Basin

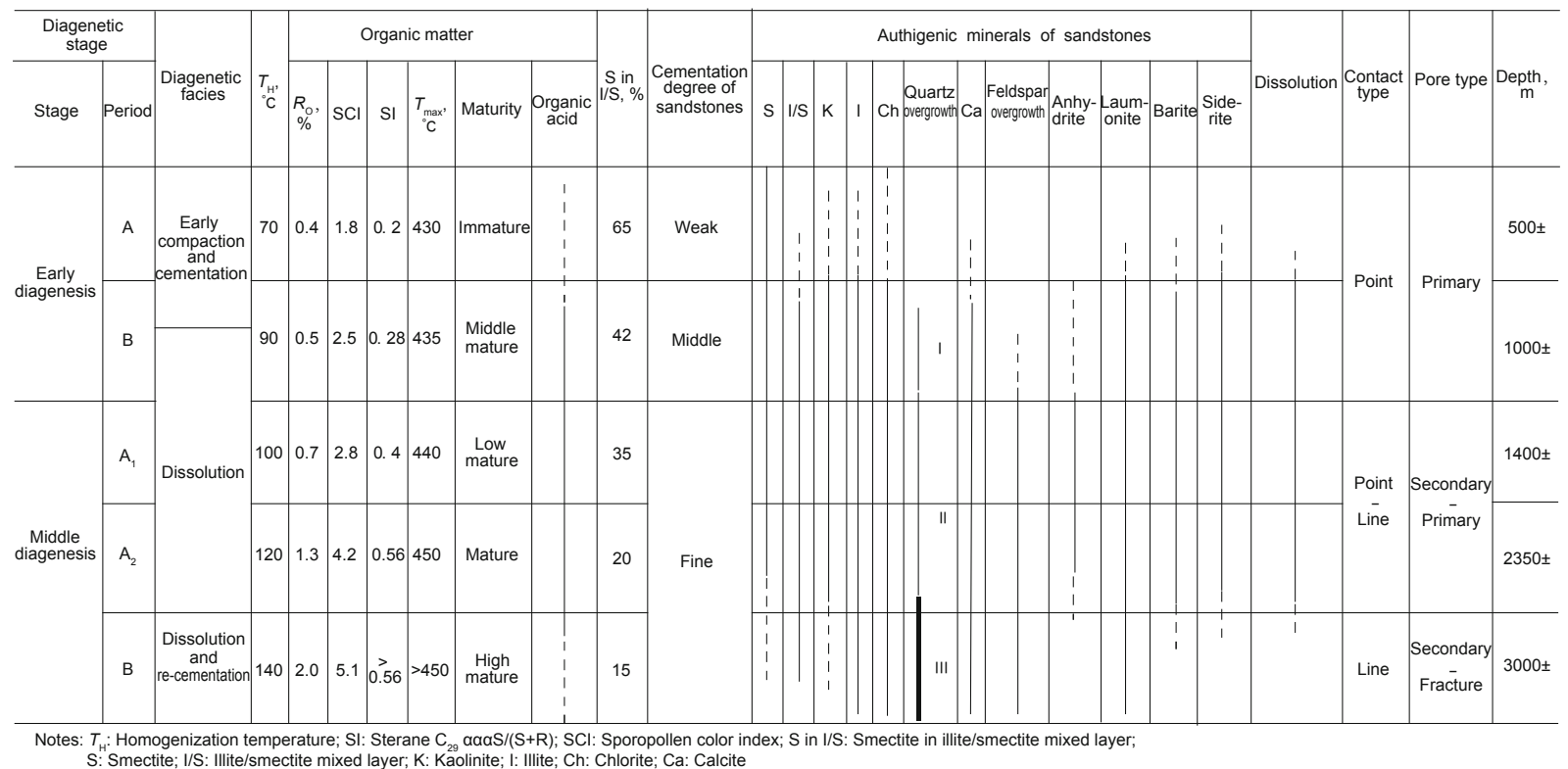

Porosity, \%

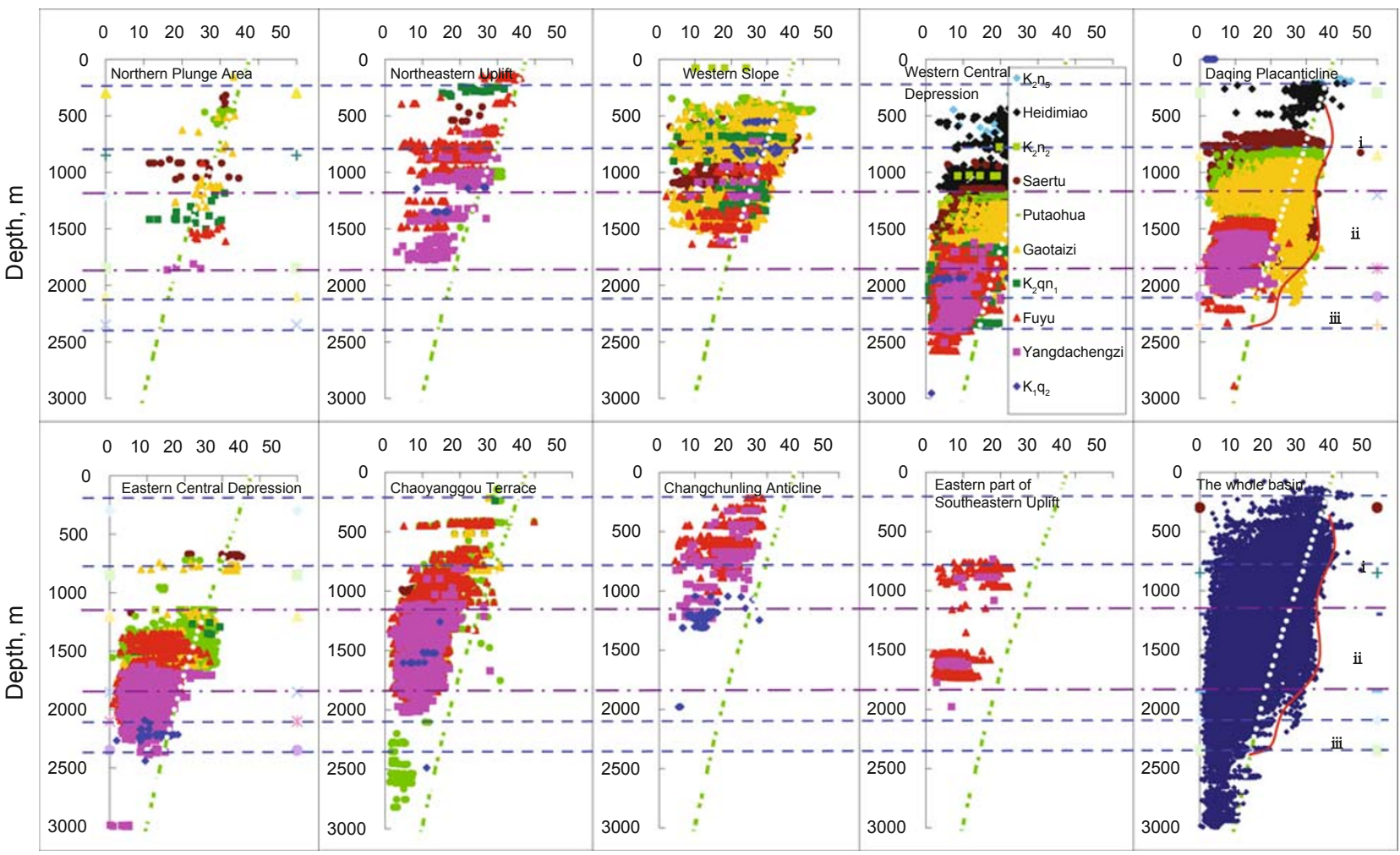

Fig. 2 Distribution of the anomalously high porosity zones in the middle-shallow horizons of the northern Songliao Basin

\section{Genesis of the anomalously high porosity}

\section{zones}

\subsection{Clay coatings}

As Bloch's research shows, the causes of the anomalously high porosity zones mainly include: (1) grain coats and grain rims, (2) emplacement of hydrocarbons, and (3) fluid overpressure (Bloch et al, 2002). According to the previous research (Bloch et al, 2002; Berger et al, 2009), clay coatings on quartz grains can effectively restrain the quartz cementation of quartzose sandstones and volcanoclastic rocks. Although fully enclosing and semi-enclosing clay coatings on quartz grains which restrained the quartz cementation in the reservoirs to a certain degree were found under the microscope (Fig. 4(a)), the reservoirs are mainly composed of arkose and feldspathic litharenite or lithic arkose in the middle-shallow horizons of the northern Songliao Basin. 


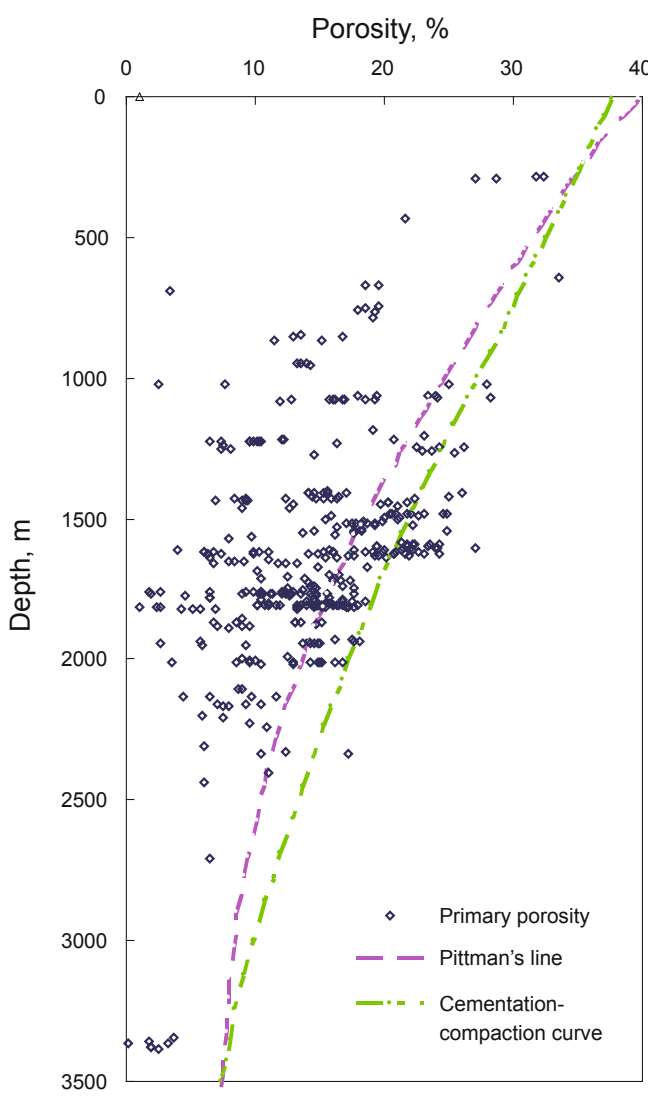

Fig. 3 Cementation-compaction curve of the northern Songliao Basin

The content of detrital quartz grains is relatively low, and the content of quartz grains with clay coatings is much lower. Therefore, clay coatings of quartz grains are not significant in preserving anomalously high porosity. Moreover, since the minimum temperature for the formation of quartz cement is $80^{\circ} \mathrm{C}$ (Walderhaug, 2000; Makowitz et al, 2006), and $T_{\mathrm{H}}$ is about $80^{\circ} \mathrm{C}$ at $750 \mathrm{~m}$, the restraint of clay coatings to quartz overgrowth mainly takes effects in the anomalously high porosity zones ii and iii.

\subsection{Overpressure}

In the overpressure formations, the fluid overpressure (difference between actual pore pressure and hydrostatic pressure at the same depth) supports part of the burial loading, and thus reduces the effects of mechanical compaction, so anomalously high porosity can be preserved (Gluyas and Cade, 1997). A theoretical derivation showed that $1 \mathrm{MPa}$ overpressure is equivalent to a $41.8 \mathrm{~m}$ decrease of burial depth (Meng et al, 2005). Well testing data collected from 270 exploratory wells in the middle-shallow horizons of the northern Songliao Basin show that the formation pressure is mainly normal hydrostatic pressure. The abnormally high pressure only appears in the center of the Gulong Sag of the Central Depression where the pressure coefficient $K$ is higher than 1.2. In the eastern Southeastern Uplift, there is abnormally low pressure, with $K<0.8$ (Xie et al, 2006). Because the distribution of the overpressure is very limited in the middle-shallow horizons of the northern Songliao Basin, and the pressure coefficient does not change significantly,

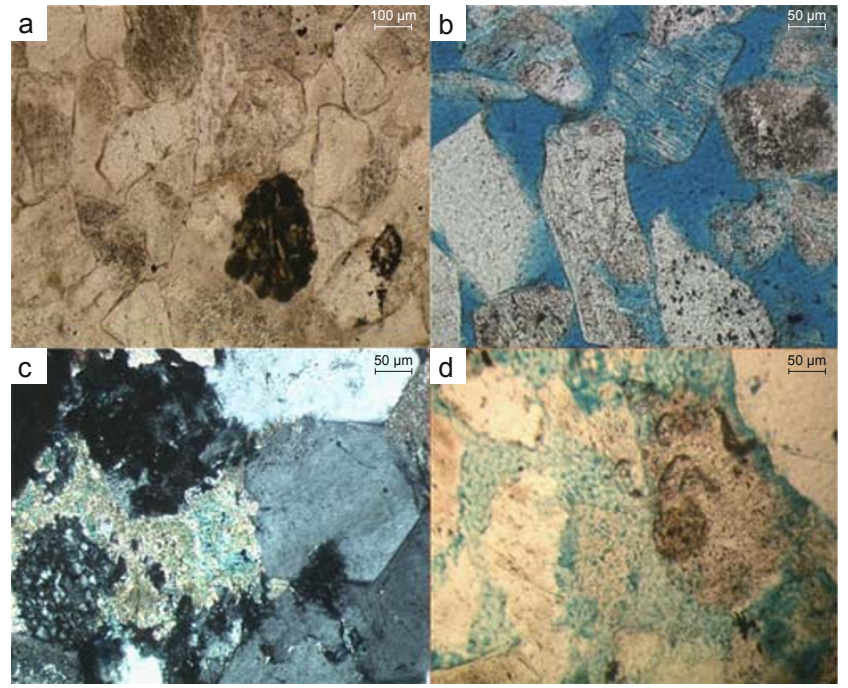

Fig. 4 Microscopic photographs of typical diagenesis a: T108 well, $1214.16 \mathrm{~m}, \mathrm{~K}_{2} \mathrm{y}_{1}$, lithic arkoses, clay coatings of clastic particles

b: D56 well, $805.01 \mathrm{~m}, \mathrm{~K}_{2} \mathrm{n}_{1}$, high porosity zone $\mathrm{i}$, lithic arkoses, dissolved pores in the feldspar particles

c: G76 well, $2107.04 \mathrm{~m}, \mathrm{~K}_{1} \mathrm{q}_{4}$, high porosity zone iii, lithic arkoses, dissolved pores in the calcite cements

d: S2-92-60 well, $1409.07 \mathrm{~m}, \mathrm{~K}_{1} \mathrm{q}_{3}$, high porosity zone iii, feldspathic litharenites, dissolved pores in the laumontite cements

the effect of overpressure or abnormally low pressure on the mechanical compaction of the sandstones is only small. The abnormally low pressure systems in the southern Songliao Basin mainly developed in the low porosity and low permeability formations (Xie et al, 2006), which may be because the region with abnormally low pressure is the fluid convergence area where cementation is relatively intense.

\subsection{Hydrocarbon emplacement}

Since Johnson proposed in 1920 that hydrocarbon emplacement (hydrocarbon invasion) halts, or at least significantly retards, the diagenesis and reduction of sandstone pore space by authigenic cements, there has been a widespread and longstanding controversy about this idea (Ramm and Bjorlykke, 1994; Midtbø et al, 2000; Bloch et al, 2002; Wilkinson et al, 2006; Meng, 2004). Most Chinese authors have accepted this idea (Shi and Wang, 1995; Cai et al, 2003). However, in the last few years several authors have questioned the significance of hydrocarbon emplacement in porosity preservation (Midtbø et al, 2000). As research of Ramm and Bjorlykke (1994) in the Viking Graben shows, the correlation between the oil saturation and porosity in Tarbort, Etine, Sratfyord, Osberg and Ness Formations is extremely poor, and the correlation coefficient is respectively $0.063,0.048,0.0188,0.270$ and -0.12 . So they believed that oil emplacement can not significantly retard the diagenesis and reduction of sandstone pore space. In order to clarify the retardation of diagenesis by the hydrocarbon emplacement in the middle-shallow horizons of the northern Songliao Basin, 50 years' saturation and porosity data in the basin were collated, but the data from exploitation wells whose oil saturations are relatively low because of 
waterflood development were omitted. More than 40,000 group oil saturation and porosity data show that there is a positive correlation between porosity and oil saturation in almost all the exploration wells (Fig. 5). The higher the oil saturation, the higher the reservoir porosity, which suggests that water-rock reactions were slowed down or even halted, and cementation and concomitant porosity reduction were retarded after hydrocarbons filled the reservoirs by turning the water-rock binary system in the original pores into a waterhydrocarbon-rock ternary system and isolating the pore fluids from the clastic particles of the reservoirs.

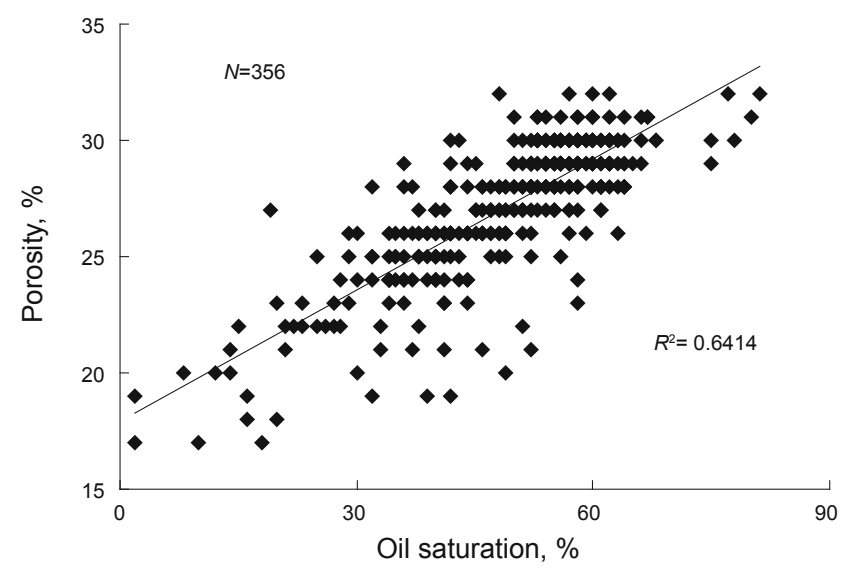

Fig. 5 Relationship between oil saturation and porosity in S166 well

The controlling factors of reservoir porosity and permeability include the sedimentary facies and diagenesis. For example, the S166 well in Fig. 5 is an exploratory well located in the Daqing Placanticline of the northern Songliao Basin. The porosity and oil saturation data of the cores sampled from sealed coring are representative of the original subsurface condition. The reservoirs of the Saertu Oil Layer Group II are composed of fine-grained or very fine-grained lithic arkoses and a little feldspathic litharenite deposited mainly in the delta front. The grain sizes of oilbearing sandstones are mainly between $0.075 \mathrm{~mm}$ and 0.163 $\mathrm{mm}$. The degree of sorting of the sandstones is between medium and fine, with a Trask sorting coefficient of 2.04.0. The clay content is mainly between $4 \%$ and $10 \%$. The reservoir heterogeneity caused by deposition is relatively weak. In other words, the changes of reservoir porosities in Fig. 5 are not caused by sedimentary facies. The depths of the samples in Fig. 5 are between $867 \mathrm{~m}$ and $933 \mathrm{~m}$, and the depth difference is only $66 \mathrm{~m}$. The difference of diagenesis caused by depth is not large, so the effects of the depth difference on the reservoir physical properties are negligible. Because the depths of the samples are in the period B of early diagenetic stage, the dissolution of reservoirs is relatively weak. Optical microscope examination of blue epoxy resinimpregnated thin sections of the reservoir rocks shows that the reservoir pores are mainly primary pores, accounting for more than $82 \%$, so the effects of dissolution on reservoir porosities can be largely excluded. As mentioned earlier, the effects of the overpressure and clay coated sandstone grains on the porosity of the reservoirs in the northern Songliao Basin may also be neglected. Consequently, the major factor causing the change of the porosity in the Saertu Oil Layer Group II is hydrocarbon emplacement. As a previous study result shows (Gao and Cai, 1997), the large-scale oil and gas migration in the northern Songliao Basin occurred mainly in the end of the Nenjiang stage $\left(\mathrm{K}_{2} \mathrm{n}\right)$, whereas the Saertu Oil Layer Group II developed in the second and third members of the Yaojia Formation $\left(\mathrm{K}_{2} \mathrm{y}\right)$, so the hydrocarbon emplacement was relatively early. Hydrocarbon emplacement effectively retards diagenesis and its concomitant porosity reduction. The burial history of S166 well shows that at the time of hydrocarbon emplacement the buried depth of the Saertu Oil Layer Group II was $589 \mathrm{~m}$ which was $353 \mathrm{~m}$ deeper than that of today. The influence of hydrocarbon emplacement on retarding diagenesis and concomitant porosity reduction of sandstones is very important in the range of the oil window, and especially has a great significance to the formation of anomalously high porosity zones ii and iii in the Central Depression of the basin. The Saertu Oil Layer Group II developed in high porosity zone ii, but it does not mean that all the sandstone bodies in the Saertu Oil Layer Group II developed abnormally high porosity. In the samples with porosity between $17 \%-33 \%$, only the sandstones on the right of the normal compaction-cementation trend line in the Fig. 2 belong to abnormally high porosity zones. Even in a single sandstone body, the reservoir porosity is higher in the part of the reservoir with higher oil saturation. The oil saturation and porosity of reservoirs are mutually related.

\subsection{Dissolution}

\subsubsection{Meteoric water leaching}

Dissolution is often divided into two types. One is the leaching of reservoir rocks by meteoric water percolating into the reservoirs through unconformities and faults, and the other is the dissolution of reservoir rocks by organic acids generated by mudstones. There are good correlations among the anomalously high porosity zones of reservoirs, low organic acid concentration and low salinity of the formation water in the Western Slope, Northern Plunge Area and part of the Northeast Uplift in the northern Songliao Basin (Fig. 6 ), which suggests that the anomalously high porosity of

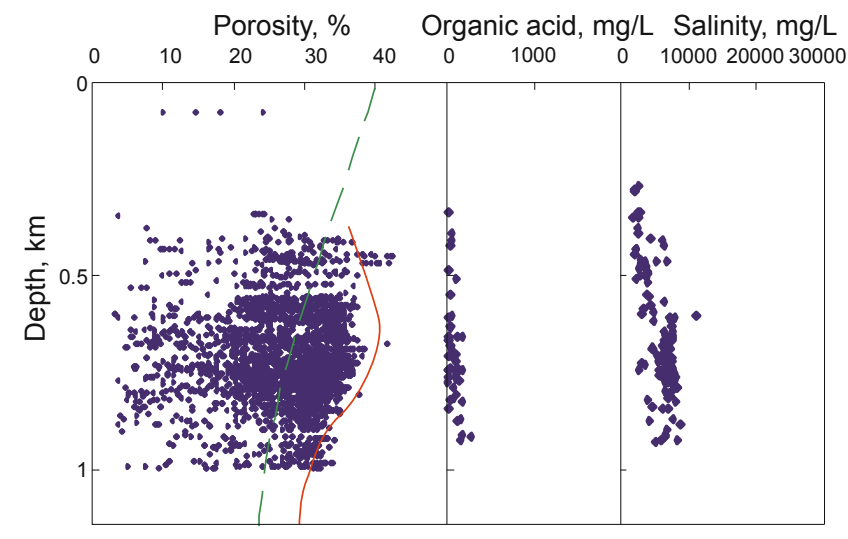

Fig. 6 Relationship among porosity, formation water salinity and organic acids of the reservoirs in the Western Slope 
the reservoirs is closely related to the activities of meteoric water. The meteoric water seeping downward dissolved unstable minerals in the reservoirs, forming the secondary porosity and increasing the porosity. It also mixed with the formation water, which reduced the salinity and organic acid concentration of formation water. At the same time, the cool meteoric water in the downward seepage flow decreased the temperature of the formation water, forming a low geothermal gradient zone (Lou et al, 2006). In the area of meteoric water activity, the lowest geothermal gradient is only $1.67^{\circ} \mathrm{C} / 100$ $\mathrm{m}$, and is generally less than $3.7^{\circ} \mathrm{C} / 100 \mathrm{~m}$, far less than the average geothermal gradient of middle-shallow horizons in the northern Songliao Basin $\left(4.41^{\circ} \mathrm{C} / 100 \mathrm{~m}\right)$. The activity of meteoric water dissolved the feldspars and carbonate cements of the reservoirs and formed the anomalously high porosity zone $\mathrm{i}$ in the Western Slope, North Plunge Area and part of the Northeast Uplift. The dissolved pores in feldspar grains and intergranular enlarged pores of the reservoir rocks in the $\mathrm{J} 71$, J72, D56 and D22 wells were observed under the microscope (Fig. 4(b)). However, in other diagenetic areas, the activities of meteoric water were weak. At present the lower part of the anomalously high porosity zone $\mathrm{i}$ in these diagenetic areas is mainly in the B period of the early diagenetic stage. The organic matter is in a semi-mature stage and can generate organic acids. The content of organic acids in the formation water is relatively high. Therefore, the formation of the anomalously high porosity zone $i$ has a close relationship with the dissolution of the reservoirs by organic acids.

5.4.2 Dissolution by diagenetic fluids generated by organic matter decarboxylation and clay mineral transformation

The kerogens generated more and more organic acids and $\mathrm{CO}_{2}$ with the increase of organic matter maturity. In the low mature and mature stage, the acids and $\mathrm{CO}_{2}$ dissolved in water, percolated into the reservoirs from mudstones, dissolving feldspars (Fig. 4(b)), laumontite cements (Fig. 4(d)) and carbonate cements (Fig. 4(c)) of the reservoir rocks, and forming secondary porosity (Fig. 4(c), Fig. 7). Therefore, there is a close correlation between the high concentration of organic acid in the formation water and the anomalously high porosity zones ii and iii (Fig. 7). Moreover, large amounts of hydrogen ions were expelled from mudstones during the transformation from smectite to illite (Hower et al, 1976), which further increased the acidity of the diagenetic fluids. The interlayer water expelled from the smectites in the clay mineral transformations got into sandstone pores, providing carriers for the organic acid migration. This was very important for the formation of secondary porosities. Thus, there are close correlations among anomalously high porosity zones ii and iii, the high organic acid concentration zone and the rapid clay mineral transformation zones I and II (Fig. 7). The thick dark mudstones were deposited and high volumes of hydrocarbons were generated in the Central Depression of the Songliao Basin. Therefore, the decarboxylation of organic matter and the transformation of clay minerals are significant for the formation of anomalously high porosity zones in this region. Large amounts of water, expelled in the transformation from smectite to illite, diluted the original formation water, reducing its salinity in the Central Depression. The salinity of the Fuyu and Yangdachengzi Oil Layers is in the range of 2,000 mg/L - 4,000 mg/L in the Central Depression, while the salinity of surrounding regions is in the range of $4,000 \mathrm{mg} / \mathrm{L}$ - 6,000 mg/L (Lou et al, 2006). The microscope observations

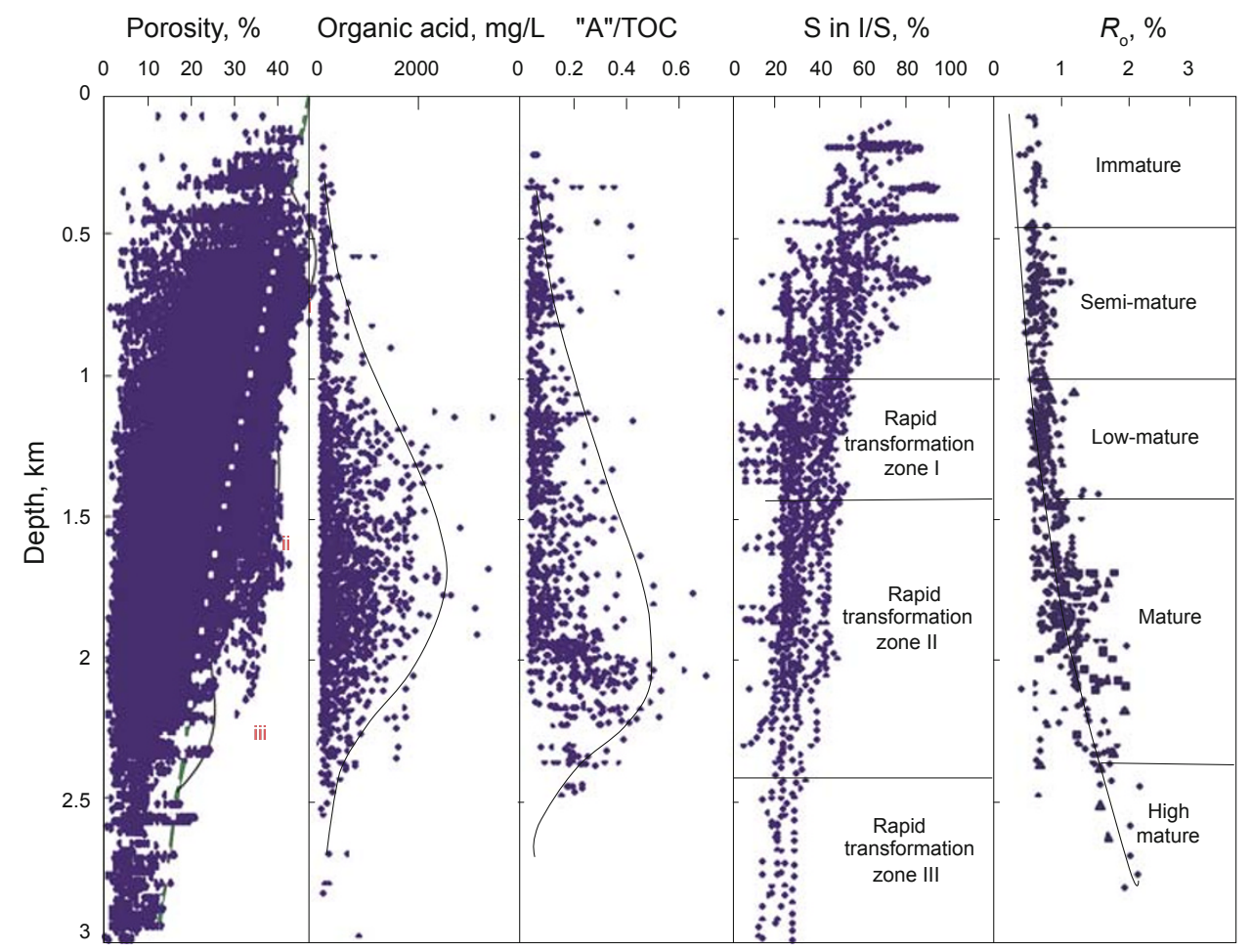

Fig. 7 Anomalously high porosity zones and the controlling factors in the middle-shallow horizons of the northern Songliao Basin 
of 1271 blue epoxy resin-impregnated thin sections show that three high porosity zones are mainly formed by the dissolution of unstable minerals and rock debris in acids. Most are feldspars (Fig. 4(c)), and the rest are debris of acidic volcanic rocks, calcite cement (Fig. 4(c)) and laumontite cement (Fig. $4(d))$.

\subsection{Lithology and sedimentary facies}

Besides the four main causes of the formation of anomalously high porosity zones proposed by Bloch et al (2002), our research showed that the lithology also had relatively significant influence on their formation (Table 2), and the reservoirs in the anomalously high porosity zones were mainly formed in strong hydrodynamic depositional environments. For example, the reservoirs with anomalously high porosity in the Member 3 and Member 4 of the Quantou Formation were predominantly deposited in meandering rivers, distributary channels and underwater distributary channels. $60 \%$ and $70 \%$ of the reservoirs respectively in the anomalously high porosity zone ii and iii were deposited in various kinds of main channels. The lithology of the reservoirs is mainly well-sorted lithic arkoses and feldspathic litharenites with low clay contents. In zones i, ii and iii, the average feldspar content is $29.2 \%, 37.8 \%$ and $33.8 \%$ respectively. The clay content is $5.2 \%, 5.6 \%$ and $4.2 \%$ respectively, and the sorting coefficient is generally less than 2.5.

Table 2 Sedimentary facies and lithology of the anomalously high porosity zones in the middle-shallow horizons of the northern Songliao Basin

\begin{tabular}{|c|c|c|c|c|c|}
\hline $\begin{array}{l}\text { Anomalously } \\
\text { high porosity } \\
\text { zones }\end{array}$ & $\begin{array}{c}\text { Porosity, } \\
\text { min-max } \\
\text { average(sample number) }\end{array}$ & Lithology & $\begin{array}{l}\text { Sorting } \\
\text { coefficient }\end{array}$ & $\begin{array}{c}\text { Clay content, } \\
\text { min-max } \\
\text { average(sample number) }\end{array}$ & $\begin{array}{c}\text { Sedimentary facies } \\
\text { (Member } 3 \text { and Member } 4 \text { of } \\
\text { the Quantou Formation) }\end{array}$ \\
\hline \multirow{2}{*}{$\mathrm{i}$} & $31.1-42.6$ & \multirow{2}{*}{$\begin{array}{c}\text { Lithic arkose: } 6 \% \text { Feldspathic } \\
\text { litharenite: } 94 \%\end{array}$} & $0.8-2.4$ & \multirow{2}{*}{$\frac{2-8}{5(23)}$} & \\
\hline & $34.3(475)$ & & $1.7(23)$ & & \\
\hline \multirow{7}{*}{ ii } & \multirow{7}{*}{$\frac{21.0-45.3}{28.4(13680)}$} & \multirow{7}{*}{$\begin{array}{c}\text { Lithic arkose: } 21 \% \\
\text { Feldspathic litharenite: } 79 \%\end{array}$} & \multirow{7}{*}{$\frac{0.2-2.8}{1.3(385)}$} & \multirow{7}{*}{$\frac{1-25}{6(516)}$} & Meandering river: $46 \%$ \\
\hline & & & & & Distributary channel: $18 \%$ \\
\hline & & & & & Subaqueous distributary \\
\hline & & & & & \\
\hline & & & & & Meandering river overflow: $24 \%$ \\
\hline & & & & & Delta front: $11 \%$ \\
\hline & & & & & Delta plain: $5 \%$ \\
\hline \multirow{5}{*}{ iii } & \multirow{5}{*}{$\frac{15.5-29.4}{20.4(466)}$} & \multirow{5}{*}{$\begin{array}{l}\text { Lithic arkose: } 31 \% \\
\text { Feldspathic litharenite: } 69 \%\end{array}$} & \multirow{5}{*}{$\frac{1.4-2.9}{2.1(49)}$} & \multirow{5}{*}{$\frac{2-10}{4(37)}$} & Distributary channel: $17 \%$ \\
\hline & & & & & $\begin{array}{c}\text { Subaqueous distributary } \\
\text { channel: } 53 \%\end{array}$ \\
\hline & & & & & \\
\hline & & & & & Meandering river overflow: $22 \%$ \\
\hline & & & & & Delta plain: $8 \%$ \\
\hline
\end{tabular}

\section{Conclusions}

1) There are three anomalously high porosity zones at the depth of $450-900 \mathrm{~m}, 1,300-1,900 \mathrm{~m}, 2,050-2,350 \mathrm{~m}$ respectively, named zone $\mathrm{i}$, zone ii and zone iii from top to bottom. Zone i and zone ii are distributed in the whole region except the Southeastern Uplift, and zone iii is only distributed in the diagenetic areas of the Central Depression.

2) The Heidimiao Oil Layer is mainly distributed in zone i; the Saertu, Putaohua and Gaotaizi oil layers are located in the zone i and zone ii; the Fuyu and Yangdachengzi oil layers are situated in zone ii and zone iii.

3) Zone i was formed by meteoric water leaching as well as organic acid dissolution. Zone ii and zone iii were dominantly formed by organic acid dissolution. $\mathrm{H}^{+}$generated by clay mineral transformation and the retardation of the cementation of the sandstones by hydrocarbon emplacement are also important for the formation of zone ii and zone iii.

4) The anomalously high porosity zones are mainly developed in well-sorted lithic arkoses and feldspathic litharenites with low clay contents deposited in meandering rivers, distributary channels and underwater delta distributary channels.

\section{Acknowledgements}

This study is supported by the National Natural Science Foundation (Grant No. 40872076).

\section{References}

Berger A, Gier S and Krois P. Porosity-preserving chlorite cements in shallow-marine volcaniclastic sandstones: Evidence from Cretaceous sandstones of the Sawan gas field, Pakistan. AAPG Bulletin. 2009. 93(5): 595-615

Bloch S, Lander R H and Bonnell L. Anomalously high porosity and permeability in deeply buried sandstone reservoirs: origin and predictability. AAPG Bulletin. 2002. 86(2): 301-328

Cai J G, Zhang Z H, Zhu X M, et al. Hydrocarbon filling and chemical diagenesis evolution of the clastic reservoir of the Paleogene in Dongying Sag. Petroleum Exploration and Development. 2003. 30(3): 79-84 (in Chinese)

Ehrenberg S N and Nadeau P H. Sandstone vs. carbonate petroleum reservoirs: A global perspective on porosity-depth and porositypermeability relationships. AAPG Bulletin. 2005. 89(4): 435-445

Ehrenberg S N, Nadeau P H and Aqrawi A A M. A comparison of Khuff and Arab reservoir potential throughout the Middle East. AAPG Bulletin. 2007. 91(3): 275-286

Ehrenberg S N, Nadeau P H and Steen $\varphi$. A megascale view of reservoir 
quality in producing sandstones from the offshore Gulf of Mexico. AAPG Bulletin. 2008. 92(2): 145-164

Gao R Q and Cai X Y. Formation Conditions and Distribution Rules of Oilfields in the Songliao Basin. Beijing: Petroleum Industry Press. 1997. 188-218 (in Chinese)

Gluyas J and Cade C A. Prediction of porosity in compacted sands. In: Kupecz J A, Gluyas J G and Bloch S, eds., Reservoir Quality Prediction in Sandstones and Carbonates. AAPG Memoir. 1997. 69: 19-27

Hower J, Eslinger E V, Hower M E, et al. Mechanism of burial metamorphism of argillaceous sediment: 1. Mineralogical and chemical evidence. Geol. Soc. Am. Bull. 1976. 87(5): 725-737

Huang W B, Lu S F, Meng Y L, et al. Prediction of the secondary porosity zone of the Fuyu oil layer in the west of the Daqing Placanticline. Acta Sedimentologica Sinica. 2009. 27(3): 419-426 (in Chinese)

Jiang L Z, Niu J Y, Zhang Q C, et al. Major factors analysis on controlling the formation of favorable reservoirs in deep levels of the Bohai Bay Basin. Geological Review. 2009. 55(1): $73-78$ (in Chinese)

Lou Z H, Cheng J R and Jin A M. Origin and evolution of the hydrodynamics in sedimentary basins - A case study of the Songliao Basin. Acta Sedimentologica Sinica. 2006. 24(2): 193-201 (in Chinese)

Makowitz A, Lander R H and Milliken K L. Diagenetic modeling to assess the relative timing of quartz cementation and brittle grain processes during compaction. AAPG Bulletin. 2006. 90(6): 873-885

Meng Y L. Study on diagenesis and numerical modeling of the Shahejie Formation in an overpressure setting in the Qibei Depression. China University of Geosciences (Beijing) PhD thesis. 2004. 33-42 (in Chinese)

Meng Y L, Gao J J, Liu D L, et al. Diagenetic facies analysis and anomalously high porosity zone prediction in the Yuanyanggou Area in the Liaohe Depression. Journal of Jilin University (Earth Science Edition). 2006. 36(2): 227-233 (in Chinese)

Meng Y L, Gao Y T, Wu H Y, et al. Regional diagenetic regularity and controlling factors of middle-shallow horizons in the northern Songliao Basin. Journal of Palaeogeography. 2010. 12(1): 97-106 (in Chinese)

Meng Y L, Jiang W Y, Liu D L, et al. Reservoir porosity prediction and its evolving history modeling: a case of the Shuangqing region in the Liaohe West Depression. Acta Sedimentologica Sinica. 2008a. 26(5): 780-788 (in Chinese)

Meng Y L, Li Y G, Niu J Y, et al. A discussion of factors controlling porosity of deep-buried clastic reservoirs in the northern Bohai Bay Basin. China Offshore Oil and Gas. 2007. 19(3): 154-156 (in Chinese)

Meng Y L, Liu D L, He R, et al. Diagenetic field analysis and porosity prediction of the Shaer Member $\left(\mathrm{Es}_{2}\right)$ in overpressures setting in the Qibei Depression. Acta Sedimentologica Sinica. 2005. 23(3): 389396 (in Chinese)

Meng Y L, Xiu H W, Meng F J, et al. Prediction of secondary pore zones in reservoirs with Rock-Eval data of mudstone. Natural Gas Industry. 2008b. 28(10): 41-43 (in Chinese)

Midtbø R E A, Rykkje J M and Ramm M. Deep burial diagenesis and reservoir quality along the eastern flank of the Viking Graben: Evidence for illitization and quartz cementation after hydrocarbon emplacement. Clay Minerals. 2000. 35(1): 231-241

Pittman E D and Larese R E. Compaction of lithic sands: experimental results and applications. AAPG Bulletin. 1991. 75(8): 1279-1299

Ramm M and Bjorlykke K. Porosity/depth trends in reservoir sandstones; assessing the quantitative effects of varying porepressure, temperature history and mineralogy, Norwegian Shelf data. Clay Minerals. 1994. 29(4): 475-490

Shao H M, Liu Z J, Wang C, et al. Diagenesis and pore evolution of deep sandstone in the north of the Songliao Basin. Global Geology. 2005. 24(1): 58-62 (in Chinese)

Shi J A and Wang Q. A discussion of the main controlling factors on the properties of clastic gas reservoirs. Acta Sedimentologica Sinica. 1995. 13(2): 128-139 (in Chinese)

Sruoga P and Rubinstein N. Processes controlling porosity and permeability in volcanic reservoirs from the Austral and Neuquén basins, Argentina. AAPG Bulletin. 2007. 91(1): 115-129

Walderhaug O. Modeling quartz cementation and porosity in Middle Jurassic Brent Group sandstones of the Kvitebjørn Field, northern North Sea. AAPG Bulletin. 2000. 84(9): 1325-1339

Wang C, Zhao H L, Shao H M, et al. Formation time of secondary pores in the sandstone and hydrocarbon reservoir of the Denglouku Formation in the Songliao Basin. Acta Petrologica et Mineralogica. 2007. 26(3): 253-258 (in Chinese)

Wilkinson M, Haszeldine R S and Fallick A E. Hydrocarbon filling and leakage history of a deep geopressured sandstone, Fulmar Formation, United Kingdom North Sea. AAPG Bulletin. 2006. 90(12): 19451961

Wu H Y, Liang X D, Xiang C F, et al. Syncline reservoir characteristics and accumulation mechanisms in the Songliao Basin. Science in China (Series D: Earth Sciences). 2007. 37(2): 185-191 (in Chinese)

Xiao L H, Meng Y L, Niu J Y, et al. Diagenetic history and diagenetic stage prediction of the Shahejie Formation in the Qikou Sag. Chinese Journal of Geology. 2005. 40(3): 346-362 (in Chinese)

Xie X N, Li S T and Liu X F. Basin Fluid Dynamics in Abnormally Pressured Environments. Wuhan: China University of Geosciences Press. 2006. 162-178 (in Chinese)

Xie X N, Cheng J M and Meng Y L. Basin fluid flow and associated diagenetic processes. Acta Sedimentologica Sinica. 2009. 27(5): 863871 (in Chinese)

Xing S Q and Jiang H Q. Continental sandstone reservoir properties and diagenesis in the Songliao Basin. Haerbin: Heilongjiang Science and Technology Press. 1992. 61-90 (in Chinese)

Ying F X, He D B, Long Y M, et al. The division of diagenetic stages in clastic rocks (People's Republic of China Oil and Gas Industry Standards). Beijing: Petroleum Industry Press. 2003. 1-9 (in Chinese)

(Edited by Hao Jie) 